With 2 plates

Printed in Great Britain

\title{
The Effect of Enzyme Treatments on Brucella abortus Cell Walls
}

\author{
By R. A. BOBO* AND J. W. FOSTER \\ Department of Microbiology and Preventive Medicine, School of Veterinary Medicine, \\ University of Georgia, Athens, Georgia, U.S.A.
}

(Received 1 April 1963)

\section{SUMMARY}

Cell walls of Brucella abortus which were treated with trypsin, 'Pronase' (a protease from Streptomyces griseus), or lysozyme were more serologically reactive than cell walls treated with ribonuclease, pepsin or lipase or those with no enzymic treatment. Ribonuclease decreased reactivity of cell wall suspensions. Electron microscopy revealed the presence of round 'plates' following treatment with certain of these enzymes. 'Plates' were also shown to be embedded in fragments of the cell wall following lysozyme treatment. Still smaller round bodies were also seen to be present. These particles are believed to be a sub-unit of $B$. abortus cell walls and are correlated with serologic reactivity.

\section{INTRODUCTION}

In 1959, Markenson, Sulitzeanu \& Olitzki described the immunizing activity of insoluble fractions of Brucella organisms which had been sonically disintegrated and concluded that these insoluble fractions were most likely cell-wall fragments. Foster \& Ribi $(1960,1962)$ showed that most of the immunizing activity of the brucellas was in the cell-wall fraction. Markenson, Sulitzeanu \& Olitzki (1962) showed that the cell walls were better antigens than the intact bacteria, and that the method of preparing the cell walls appeared to influence their activity, in that the protection index given by cell wall prepared by trypsinization was higher than that shown by cell wall prepared by sonic disintegration only. The purpose of the present work was to evaluate the antigenicity of certain preparations made from Brucella abortus and to study, in particular, some effects of enzymes on the antigenicity of Brucella cell walls.

\section{METHODS}

The culture used throughout was Brucella abortus strain 19 taken from the culture collection of the School of Veterinary Medicine, University of Georgia. Cell walls and cytoplasm of Brucella were prepared according to the method of Foster, Cowan \& Maag (1962) or Foster \& Ribi (1962). Endotoxin was prepared by the aqueous extraction of ether-treated organisms (Foster \& Ribi, 1962). Acetonesterilized organisms were prepared by adding 2 vol. of cold acetone to 1 vol. of washed brucellas in cold saline. The brucellas were adjusted to a concentration equivalent to about $50 \mathrm{mg}$. dry weight $/ \mathrm{ml}$. suspension. The suspension was re-

* Present address : Campbell Clinic, Chattanooga, Tennessee, U.S.A. 
frigerated at $0-6^{\circ}$ overnight and dried on a Buchner funnel by washing with cold acetone. Cytoplasm, endotoxin, cell walls and ether-treated whole organisms were lyophilized.

Enzymic treatment of cell walls. The enzymic treatment of cell walls was as follows. Samples of cell wall (equiv. $5 \mathrm{mg}$. dry wt.) in 0.15 M-phosphate buffer (5 ml.) were treated with the following enzyme preparations $(2.5 \mathrm{mg}$. at the $\mathrm{pH}$ values indicated): ribonuclease ( $5 \times$ cryst., Nutritional Biochemicals, Cleveland, 18, Ohio, U.S.A.), pH 7.6 ; pepsin ( $5 \times$ cryst., Nutritional Biochemicals), pH 2.5 ; lipase (Nutritional Biochemicals), pH 7.0; lysozyme (Nutritional Biochemicals), pH 7.2; trypsin (trypsin 1/250, Difco Laboratories), pH 8.2; Pronase (Streptomyces griseus protease, California Corporation for Biochemical Research, 3625 Mediford Street, Los Angeles 63, Cal., U.S.A.), pH 8.6. Controls with the same reagents as the test, but without the corresponding enzymes, were included and handled in the same way as the test suspensions. These were incubated for $3 \mathrm{hr}$ at $37^{\circ}$ in a water bath. Two ml. samples of the test and control suspensions were removed for part of the tests and the remainder centrifuged at $12,000 \mathrm{~g}$ and $0^{\circ}$ for $20 \mathrm{~min}$. The sediment was reconstituted to the original volume with $0 \cdot 15 \mathrm{M}-\mathrm{NaCl}$. The supernatant fluid and sediment from pepsin-treated cell walls were neutralized with $0 \cdot 1 \mathrm{~N}-\mathrm{NaOH}$.

Preparation of antisera. Before injection, non-living antigens were adjusted to a concentration of $1 \mathrm{mg} . / \mathrm{ml}$. in saline and tested for sterility by inoculation on tryptose and blood agar plates. Serologically negative rabbits were then given an intravenous injection of $2 \cdot 0 \mathrm{mg}$. antigen. Antisera against viable brucellas were produced by inoculation of a suspension containing about $10^{9}$ cells. These brucellas were grown on a chemically defined medium to avoid production of antibodies against culture medium ingredients. Seven days after inoculation all rabbits were bled by heart puncture, the sera collected and stored at $5^{\circ}$ without preservative.

Serological analysis. The serological reactivity of all the preparations was measured by the capillary flocculation test (Larson, 1951) with antigen dilutions with constant antibody. A parallel set of controls was routinely set up using the same antigen dilutions $+0.15 \mathrm{M}-\mathrm{NaCl}$ instead of serum. The tubes were incubated at $25^{\circ}$ and read at the end of 24 and $48 \mathrm{hr}$. The end-point adopted was the highest dilution in which a 'floc' visible with a $\times 10$ hand lens had settled to the lower meniscus in the tube. The 'floc' was readily distinguished from the more compactly sedimented control. Control dilutions showed visible flocculation only twice and then only in dilutions less than 1/10. Titres are expressed as the reciprocal of the dilution and are based on the dry weights of the various fractions; thus $1 \mathrm{mg} . / \mathrm{ml}$. was considered to be undiluted. In interpreting the results, it should be remembered that the antigens used in these tests were in different physical states (Shepard, Ribi \& Larson, 1954; Ribi, Milner \& Perrine, 1959).

Tube agglutination titres were determined in twofold dilutions of antisera in a final quantity of $0.5 \mathrm{ml}$./tube to which $0.5 \mathrm{ml}$. of standard ARS Brucella antigen (obtained through courtesy of Dr C. A. Manthei, National Animal Disease Laboratories, U.S., A.R.S., Ames, Iowa, U.S.A.) was added. An antigen + saline control was included with each test. The tubes were then incubated in a water bath at $37^{\circ}$ for $48 \mathrm{hr}$ before final readings were made. Total agglutination resulting in a completely clear supernatant fluid was scored as $4+$, and all titrations were read at this end-point. 
Electron micrographs were made with an RCA EMU-2C electron microscope. Preparations were mounted on 200-mesh copper screens covered with a thin collodion film and shadowed with chromium or platinum + palladium alloy.

\section{RESULTS}

\section{Serological activity of various Brucella abortus fractions}

The results of capillary flocculation tests with various Brucella fractions are given in Table 1. These results show that Brucella cell walls and endotoxin were the most antigenically active of the various fractions. Viable organisms showed little flocculation while ether and acetone-sterilized organisms were more reactive.

The data given in Table 2 were obtained with tube agglutination by using antisera for the various preparations and phenolized Brucella organisms of various species.

Table 1. Reciprocal flocculation titres to fractions of Brucella abortus strain 19

\begin{tabular}{|c|c|c|c|c|c|c|}
\hline \multirow{3}{*}{$\begin{array}{l}\text { Preparation } \\
\text { (equiv. } 1 \text { mg. dry wt./ } \\
\text { ml. saline) }\end{array}$} & \multicolumn{6}{|c|}{ Antiserum to } \\
\hline & $\begin{array}{c}\text { Viable } \\
\text { organisms }\end{array}$ & $\begin{array}{l}\text { Acetone- } \\
\text { sterilized } \\
\text { whole } \\
\text { organisms }\end{array}$ & $\begin{array}{c}\text { Ether- } \\
\text { treated } \\
\text { whole } \\
\text { organisms }\end{array}$ & $\begin{array}{c}\text { Cell } \\
\text { walls }\end{array}$ & Endotc & Cytoplasm \\
\hline & \multicolumn{6}{|c|}{ Reciprocal flocculation titre } \\
\hline Viable organisms & 20 & 20 & 5 & 5 & 5 & 5 \\
\hline $\begin{array}{l}\text { Acetone-sterilized whole } \\
\text { organisms }\end{array}$ & 40 & 160 & 20 & 20 & 80 & 10 \\
\hline $\begin{array}{l}\text { Ether-treated whole } \\
\text { organisms }\end{array}$ & 40 & 40 & 40 & 40 & 40 & 40 \\
\hline Cell walls & $80-160$ & 320 & 40 & $\mathbf{8 0}$ & 80 & 40 \\
\hline Endotoxin & $640-1280$ & 160 & 40 & 40 & 160 & 40 \\
\hline Cytoplasm & 10 & 20 & $\mathbf{5}$ & $\mathbf{5}$ & 40 & 40 \\
\hline
\end{tabular}

Table 2. Serological response in rabbits following the intravenous injection of Brucella abortus fractions

\section{B. abortus 19 antigens}

Viable organisms

Cell walls

Endotoxin

Cytoplasm

Acetone-sterilized whole organisms

Ether-treated whole organisms

Cell walls + ribonuclease

Cell walls + pepsin

Cell walls + lipase

Cell walls + trypsin

Cell walls + Pronase

Cell walls + lysozyme
Antiserum to

$\begin{array}{ccc}B . & B . & B . \\ \begin{array}{ccc}\text { abortus } & \text { suis } & \text { melitensis } \\ 19 & 1776 & 2500\end{array}\end{array}$

Reciprocal of serum titres in tube agglutination

$\begin{array}{rrr}640 & 640 & 320 \\ 640 & 640 & 640 \\ 1280 & 640 & 320 \\ 320 & 160 & 80 \\ 640 & 640 & 640 \\ 320 & 320 & 320 \\ 320 & 320 & 160 \\ 320 & 640 & 320 \\ 640 & 640 & 320 \\ 640 & 640 & 320 \\ 1280 & 1280 & 1280 \\ 1280 & 1280 & 1280\end{array}$


These titres showed little difference in antigenicity of viable and killed organisms. They also suggest that the distribution of $\mathbf{A}$ and $\mathbf{M}$ antigens in the cell walls did not differ from their distribution in whole organisms. Possibly there is a difference in anti-A and anti-M antibodies produced by inoculation of cytoplasm and endotoxin because the titre of Brucella melitensis was one-fourth that of $B$. abortus. There was no evidence of a differential sensitivity of $\mathbf{A}$ and $\mathbf{M}$ antigens to the enzymes used.

Effect of enzymes on cell walls. Initial evidence for enzymic effect on Brucella cell walls was a decrease in opacity following Pronase and lysozyme treatment. Lysozyme increased flocculation titres of cell-wall suspensions two- to fourfold and ribonuclease decreased the titre twofold; pepsin, lipase, Pronase or trypsin had no detectable effect.

Table 3. Reciprocal flocculation titres of enzyme-treated cell-rvall sediments and supernatant fluids to Brucella abortus strain 19 antiserum prepared with viable organisms; cell walls treated with enzymes and samples of sediment and supernatant fluids after centrifugation tested for flocculation against antiserum to whole viable B. abortus 19

Antiserum to whole viable $B$. abortus 19

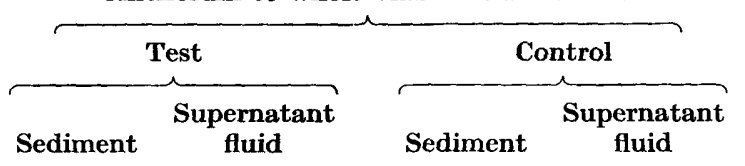

Enzyme-treated cell-wall preparations (equiv. $1 \mathrm{mg}$. preparation $/ \mathrm{ml}$.)

Cell walls + ribonuclease
Cell walls + pepsin
Cell walls + lipase
Cell walls + trypsin
Cell walls + Pronase
Cell walls + lysozyme

\begin{tabular}{rrrr}
\multicolumn{4}{c}{ Reciprocal flocculation titre } \\
40 & 10 & 160 & neg \\
80 & 20 & 80 & 10 \\
80 & 20 & 160 & neg \\
80 & 40 & 160 & neg \\
160 & 80 & 160 & neg \\
320 & 160 & 160 & neg
\end{tabular}

These results led to an examination of the relative reactivity of the sediments and supernatant fluids of the cell-wall suspension after enzyme treatment. The data given in Table 3 show that Pronase and lysozyme released significant amounts of antigen into the supernatant fluid; trypsin apparently released more antigen than lipase, pepsin or ribonuclease. Ribonuclease decreased the flocculation titre of the sediment and released little antigen into the supernatant fluid. Buffer released little soluble antigen from cell walls.

The results given in Table 4 furnish additional evidence that lysozyme increased the flocculation titre of the cell walls. Decreased activity of pepsin-treated cell walls also was seen with endotoxin or cell-wall antiserum. However, the low pH value used during enzyme treatment may have caused the decreased reactivity. The antiserum for cytoplasm reacted more strongly with untreated cell-wall preparations than with enzyme-treated preparations. This might have been due to the effect of the enzymes on cytoplasm which may have contaminated the cell walls.

Morphological study of enzyme-treated Brucella cell walls. From a study of the 
electron micrographs (Pls. 1 and 2, figs. 1-7) it is apparent that the trea tment of cell walls with enzymes resulted in not only a loss of Brucella cell-wall rigidity but also a loss of cell-wall integrity. Salton (1960) concluded that the enzymes ribonuclease, trypsin and lipase could be used without destroying rigidity of, or apparently degrading, the wall structure. From a comparison of $\mathrm{Pl}$. 1, fig. 1, which is a control specimen, with $\mathrm{Pl}$. 1, figs. 3-5, it is apparent that there was a degradation of Brucella abortus cell walls with all of these enzymes, as well as with pepsin (Pl. 1, fig. 2) and Pronase (Pl. 2, fig. 7).

Table 4. Reciprocal flocculation titres of Brucella abortus strain 19 fractions to $B$. abortus 19 fraction antisera

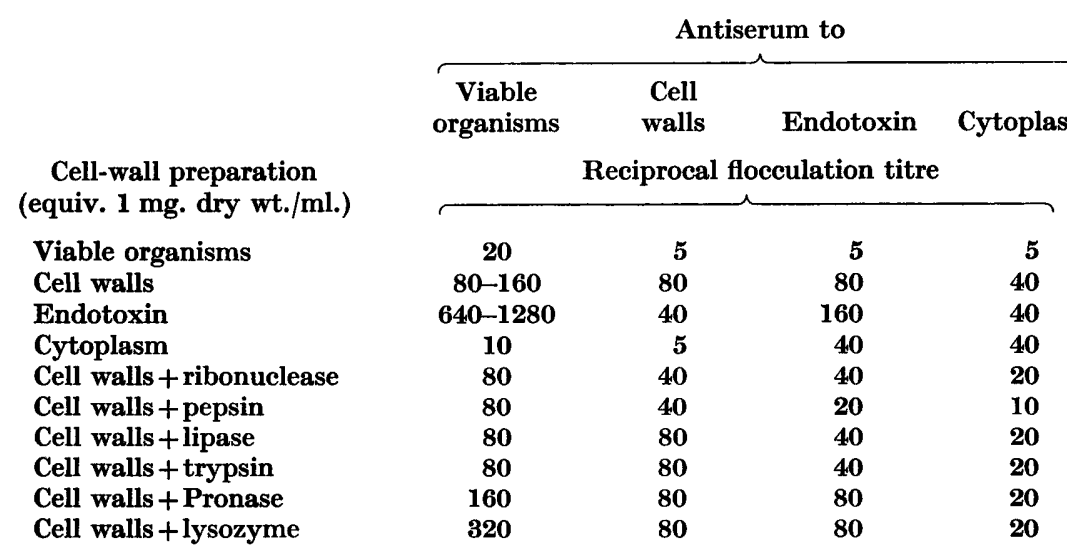

Salton (1960) also showed that after treatment with lysozyme, the cell walls of Rhodospirillum rubrum lost rigidity and became spherical. This he attributed to the release by lysozyme of alanine, glutamic acid, diaminopimelic acid, and glucosamine. Plate 2, figs. $6 a, b$, are electron micrographs of Brucella cell walls treated with lysozyme. In comparing these figures with $\mathrm{Pl}$. 1 , fig. 1 , it seems that there is not so much a loss of cell rigidity as there is a loss in cell-wall integrity. The small round 'plates' seen in $\mathrm{Pl} .1$, fig. 2, and Pl. 2, fig. $6 b$, in particular, which vary in size from less than $0 \cdot 1 \mu$ to about $0 \cdot 3 \mu$, are too small to be intact cell walls which, owing to lysozyme and Pronase, have lost their rigidity and assumed a spherical shape. The flattening might be an artifact. Although there is certainly a decrease in the size of the intact cell wall treated with any of the enzymes, this decrease is not sufficient to account for the extremely small size of the 'plates'. If the supernatant fluid, separated from the lysozyme-treated cell walls at $3800 \mathrm{~g}$ for $1 \mathrm{hr}$ at $0^{\circ}$, is centrifuged for successive $30 \mathrm{~min}$. periods at $12,000 \mathrm{~g}$ and $90,000 \mathrm{~g}$ at $0^{\circ}$, fragments are sedimented which contain 'plates'. Further centrifugation at $140,000 \mathrm{~g}$ and $0^{\circ}$ sediments smaller fragments (Pl. 2, fig. $6 b$ ) which still contain 'plates'. In these pictures some 'plates' seem to be held in membranous material. The appearance is that of a defined structural component, a 'plate', in the cell wall. There also are still smaller particles (Pl. 2, fig. 6a) visible in disintegrating cell walls, and in the background material. These are similar to those seen in Escherichia coli by Weidel, Frank \& Martin (1960). The particles released by lysozyme and sedimented from 
a supernatant fluid as above react to high titre (greater than 1/5120) with Brucella abortus antiserum. It appears that enzymic treatment of Brucella cell walls has brought about a degradation of the structure and hence a loss of cell-wall integrity.

\section{DISCUSSION}

The results of the present work confirm earlier reports (Markenson et al. 1959, 1962; Foster \& Ribi, 1960, 1962) that potent antigenic substances are to be found in the cell walls of Brucella abortus. The apparent increase in serological reactivity obtained when Brucella cell walls were treated with trypsin, Pronase or lysozyme is of significance in view of the recent findings of Olitzki \& Sulitzeanu (1958) and Markenson et al. (1962). The former workers treated Brucella cell walls with trypsin and intact organisms with lysozyme. They observed that lysozyme treatment enhanced the antigenicity of their preparations and concluded that the enzyme caused more efficient release of antigen by breaking up cell walls; they also found that pepsin inactivated some antigens in the cell wall. The results of the present study are compatible with their findings (Tables 3 and 4). Markenson et al. (1962) found that trypsin digestion of ethanol-treated brucellas yielded cell walls which were more immunogenic than those obtained by sonic disintegration only, and sonic disintegration of trypsin cell wall further enhanced immunogenicity. The results in the present work are less convincing, but cannot be directly compared since the former study was made in vivo.

It is interesting to note that viable brucellas gave low flocculation titres (Tables 1 and 4) with the antisera tested. Viable brucellas probably release less antigen than brucellas which have been altered by acetone (Olitzki \& Sulitzeanu, 1958; present paper, Table 1) or ether (Foster \& Ribi, 1962).

Electron micrographs show that maximum disintegration of cell walls follows treatment with lysozyme and Pronase. Lesser degrees of dispersal occurred with other enzymes, but in all cases round 'plates' were released. Increased flocculation titres were correlated to some extent with degrees of dispersion, and the 'plates' may account for the flocculating activity of the supernatant fluids shown in Table 3. Markenson et al. $(1959,1962)$ described similar particles of cell walls which they considered to be cell-wall fragments; we concur in this opinion. It seems possible that the 'plates' and smaller round particles observed in the present work are normally occurring structural sub-units. Pl. 2, figs. $6 a, b$, supports this idea. If so the cell-wall structure may be different from that seen in Escherichia coli (Weidel et al. 1960). However, their cell walls were treated with base which would probably release some cell-wall material from Brucella abortus (Olitzki \& Sulitzeanu, 1958; Olitzki, 1960; Foster \& Ribi, 1962). The $E$. coli cell walls were also treated with sodium dodecyl sulphate which is known to affect the state of aggregation of Brucella antigens (Miles \& Pirie, 1939) and these differences in treatment make direct comparison impossible. The possibility cannot be overlooked that the 'plates' might be derived from cell membrane which adhered to the cell wall. The indiscriminate effects of the several enzymes in producing 'plates' might indicate action on a membrane. Finally, the increase of flocculation titres by an increase in dispersion of the cell wall poses the following questions: is this increase due simply to an increase in surface area exposed, or is it due to exposure of a new and 
different surface? That the inner surface of the cell wall may differ from that of the outside has been shown by electron micrography of the cell wall of a Spirillum (Houwink, 1953) and E. coli (Weidel et al. 1960).

We wish to thank Dr T. A. Maag of this department for assistance in preparation of the final enlargements. This investigation was supported, in part, by a research grant (E-1247) from the National Institute of Allergy and Infectious Diseases, and by a training grant (2E-197) U.S. Public Health Service. Part of this work is taken from a thesis presented by the senior author in partial fulfilment of the requirements for the degree of Master of Science, University of Georgia, 1962. It was presented, in part, at the Annual Meeting for the Society for Microbiology, Cleveland, Ohio, 6 May 1963.

\section{REFERENCES}

Foster, J. W., Cowan, R. M. \& MaAg, T. A. (1962). Rupture of bacteria by explosive decompression. J. Bact. 83, 330.

Foster, J. W. \& RiBi, E. (1960). The role of the cell wall of Brucella abortus in immunity. Bact. Proc. 1960.

Foster, J. W. \& RIBI, E. (1962). The role of the cell wall of Brucella abortus in immunity. J. Bact. 84, 258.

Houwink, A. L. (1953). A macromolecular mono-layer in the cell wall of Spirillum sp. Biochim. biophys. acta, 10, 360.

LARSON, C. L. (1951). Studies on thermostable antigens extracted from Bacterium tularense and from tissues of animals dead of tularemia. J. Immunol. 66, 249.

Markenson, J., Sulitzeanu, D. \& Olitzki, A. (1959). Immunizing properties of insoluble cell material derived from Brucella. Nature, Lond. 183, 1693.

Markenson, J., Sulitzeanu, D. \& Olitzki, A. (1962). Immunogenic activity of Brucella cell wall. Brit. J. exp. Path. 39, 219.

Mrres, A. A. \& Pirie, N. W. (1939). The properties of antigenic preparations from Brucella melitensis. II. Serological properties of the antigens. Brit. J. exp. Path. 20, 109.

Outzzi, A. L. (1960). The antigenic relationship between phenol extracted bacterial deoxyribonucleic acid and other soluble antigens of brucellae studied with the aid of the agar-gel precipitation technique. Brit. J. exp. Path. 41, 623.

Olitzki, A. L. \& Sulitzeanu, D. (1958). Studies on the antigenic structure of Brucella suis with the aid of agar-gel precipitation technique. Brit. J. exp. Path. 39, 219.

Ribi, E., Milner, K. C. \& Perrine, T. D. (1959). Endotoxic and antigenic fractions from the cell wall of Salmonella enteritidis. J. Immunol. 82, 75.

Salton, M. R. S. (1960). Microbial Cell Walls. Ciba Lectures in Microbial Biochemistry. New York: John Wiley and Sons Inc.

ShePard, C. S., Ribi, E. \& Larson, C. L. (1954). Electron microscopically revealed structural elements of Bacterium tularensis and their in vitro and in vivo role in immunologic reactions. J. Immunol. 75, 7.

Weidel, W., Frank, H. \& Martin, H. H. (1960). The rigid layer of the cell wall of Escherichia coli strain B. J. gen. Microbiol. 22, 185. 
R. A. Bobo and J. W. Foster

\section{EXPLANATION OF PLATES}

\section{Plate 1}

Fig. 1. Control: Brucella abortus strain 19 cell walls untreated with enzyme.

Fig. 2. B. abortus cell walls treated with pepsin.

Fig. 3. $B$. abortus cell walls treated with lipase.

Fig. 4. B. abortus cell walls treated with ribonuclease.

Fig. 5. B. abortus cell walls treated with trypsin.

\section{Prate 2}

Fig. 6a. B. abortus cell walls treated with lysozyme.

Fig. 6b. Particles from lysozyme-treated cell walls, not sedimented at $90,000 \mathrm{~g}$ in $2 \mathrm{hr}$. but sedimented at $140,000 \mathrm{~g}$.

Fig. 7. B. abortus cell walls treated with Pronase. 

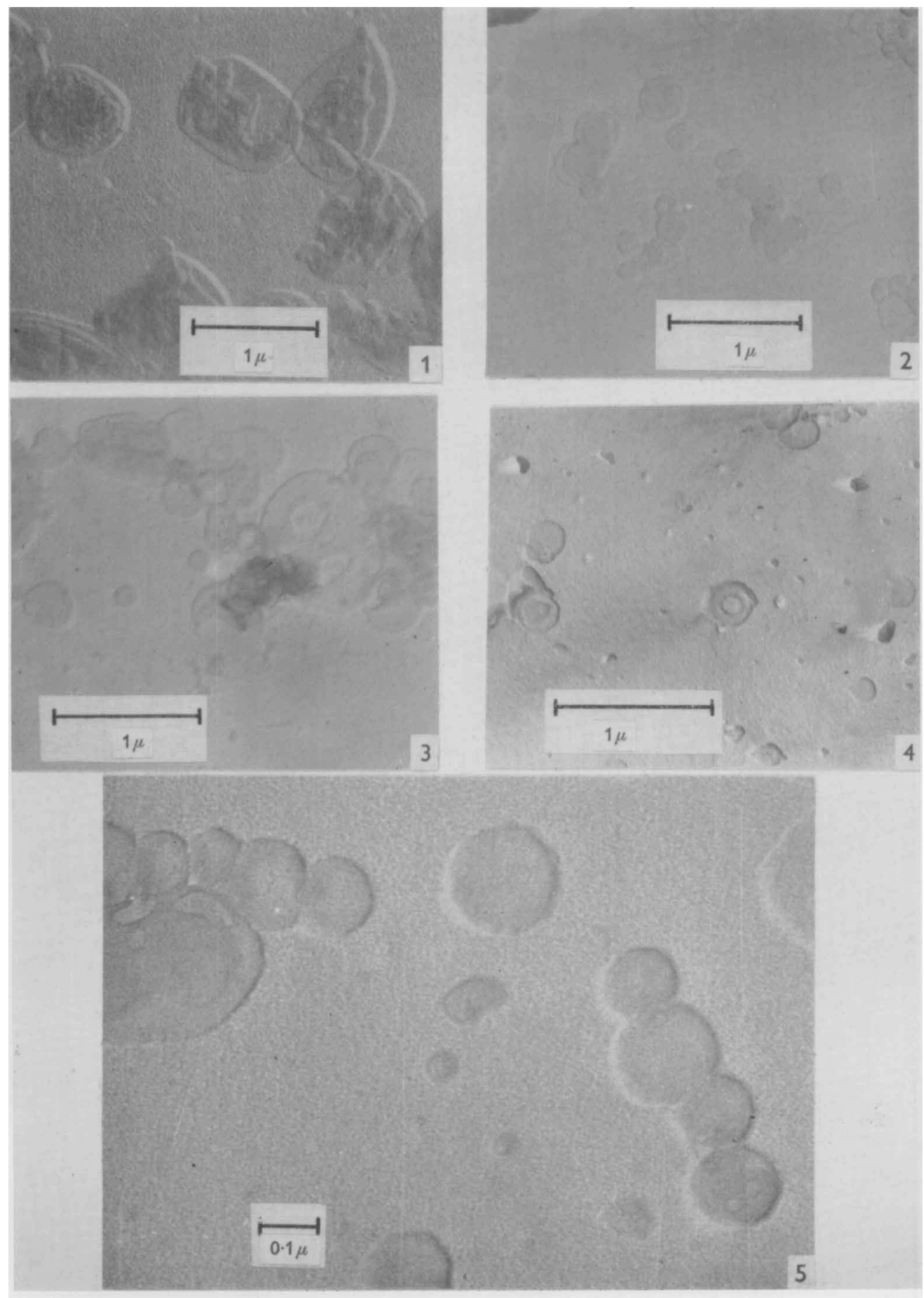

R. A. BOBO AND J. W. FOSTER

(Facing p. 8) 
Journal of General Microbiology, Vol. 34, No. 1

Plate 2

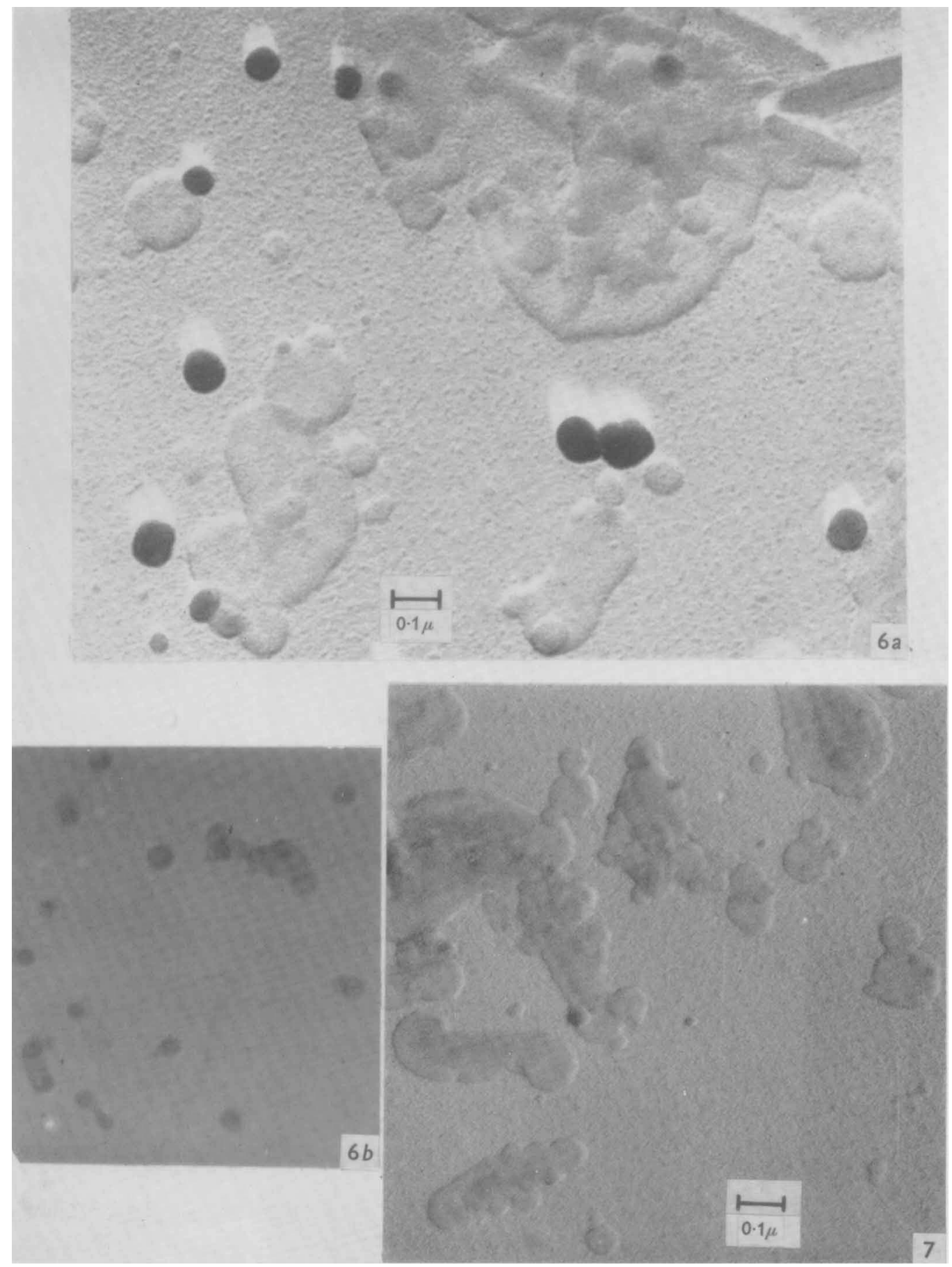

R. A. BOBO AND J. W. FOSTER 